\title{
Comparison of Laparascopic and Open Adrenalectomy
}

\author{
Onur Dülgeroğlu ${ }^{1,2}$ (iD , Tayfun Bilgiç ${ }^{3}$ (iD , Mehmet Hacıyanlı' (iD
}

${ }^{1}$ Department of General Surgery, İzmir Katip Çelebi University, School of Medicine, Izmir, Turkey

${ }^{2}$ Acibadem Mehmet Ali Aydinlar University, Vocational School of Health Sciences, Istanbul, Turkey ${ }^{3}$ Nişantaşı University, Vocational School of Health Sciences, Istanbul, Turkey

Onur DÜLGEROĞLU, M.D.

Tayfun BiLGiç, Asist. Prof.

Mehmet HACIYANLI, Prof.

Correspondence: Onur Dülgeroğlu Acibadem Mehmet Ali Aydinlar University, Vocational School of Health Sciences, Istanbul, Turkey

Phone: +905332595230

E-mail: onur.dulgeroglu@acibadem.edu.tr

\section{ABSTRACT}

Purpose: Laparoscopic adrenalectomy, which was performed successfully for the first time in 1992, has become the preferred method in adrenal surgery especially in adrenal diseases. In this study, our aim is to compare the demographic and operative data of laparoscopic and open adrenalectomies performed in the general surgery clinic of our hospital.

Methods: The records of the patients who were operated in hospital due to a surrenal mass between August 2006 and December 2012 have been retrospectively assessed. Demographic characteristics of the patients, such as age, sex, the size and location of tumors were included. Surgical indications were classified in terms of their radiologic and biochemical investigations. Type of the surgery (lateral transperitoneal laparoscopic or open approach), the incision used in these surgeries (midline, subcoastal and paramedian), the length of operation, the length of hospital stay, postoperative complications and the final pathology results were all examined.

Results: During the afformentioned period, adrenalectomy was performed in 106 patients. Eighty of these patients $(\% 75,4)$ were operated by open and 26 of them $(\% 24,6)$ by lateral transperitoneal laparoscopic surgery. Subcostal incision was used 61 of 80 patients $(\% 82,4)$, whereas 17 patients $(\% 22,9)$ were operated by midline incision and $2(\% 2,7)$ were by paramedian incision. No mortality was encountered. Operation time was statistically significantly shorter in the open group $(p<0,0166)$. Duration of hospital stay was statistically significantly longer in open group $(p<0,0083)$. Hospital stay time was statistically significantly longer in midline incision group $(p<0,0083)$. Except for the weight of masses, statistically significant difference was not found between two groups (laparascopic and open surgery) in demographic and operative features (age,gender,side,pathological diagnose, size of mass) releated to postoperative complications.

Conclusion: In carefully selected group of patients laparoscopic adrenalectomy offered lesser postoperative hospital stay than the open adrenalectomy. The longer operative time can be decreased when more experience is gained in laparascopic adrenalectomy. Laparoscopic adrenalectomy should be preferred in adrenal disease as the gold standard in centers with completed learning curve.

Keywords: Adrenalectomy; Surgery ; Laparoscopy

\section{Laparoskopik ve Açık Adrenalektominin Karşılaştırıması}

ÖZET

Amaç: IIlk olarak 1992 ylında başarılı bir şekilde gerçekleştirilen laparoskopik adrenalektomi adrenal hastalıklarda ilk tercih edilen yöntem olmaktadır. Bizim bu çalışmada amacımız; hastanemiz genel cerrahi kliniğinde yapılan laparaskopik ve açık sürrenalektomilerin demografik ve operatif sonuçlarını karşılaştırmaktır.

Method: Hastanemizde 2006 Ağustos-2012 Aralık tarihleri arasında genel cerrahi kliniğinde sürrenal kitle nedeni adrenalektomi uygulanmış hastaların kayıtları retrospektif olarak incelendi. Hastaların yaş, cinsiyet, tümör boyutu ve lokalizasyon gibi demografik özellikleri incelendi. Preoperatif klinik, radyolojik ve biyokimyasal özelliklerine göre operasyon endikasyonları gruplandırıldı. Operasyon tipi (lateral transperitoneal laparaskopik veya açık) , operasyonda kullanılan insizyon (median , subkostal , paramedian) , operasyon süreleri, ameliyat sonrası hastanede kalış süresi , postoperatif komplikasyon ve patoloji sonuçları incelendi.

Bulgular: Retrospektif olarak incelenen tarih aralığında 106 hastaya adrenalektomi uygulandı. Opere edilen hastaların 80'ine $(\% 75,4)$ acık cerrahi , 26'sına $(\% 24,6)$ ise laparaskopik lateral transperitoneal adrenalektomi uygulanmıstır. Acık cerrahi uygulanan 80 hastanın 61 'inde $(82,4 \%$ ) subkostal , 17'sinde (22,9\%) median ve 2'sinde (2,7\%) paramedian kesi kullanildığı görüldü. Herhangi bir mortaliteye rastlanmadı. Açık cerrahi uygulanan grupta operasyon sürelerinin istatistiksel olarak anlamlı kısa olduğu görüldü $(p<0,0166)$. Açık adrenalektomi uygulanan hastalarda yatıs süresinin istatistiksel olarak anlamlı yüksek olduğu görüldü $(p<0,0083)$. Median insizyonla opere edilen olguların yatıs sürelerinin istatistiksel olarak anlamlı yüksek olduğu görüldü $(p<0,0083)$. Demografik ve operatif özellikler (yaş, cinsiyet, taraf, patolojik tanı, kitle boyutu) açıından kitle ağırlığı dışında postoperatif komplikasyonlarla ilgili iki grup arasında (laparoskopik ve açik cerrahi) istatistiksel anlamlı bir fark bulunamadı.

Sonuç: Dikkatlice seçilmiş hasta gruplarında, laparaskopik adrenalektomi açık adrenalektomiye göre daha kısa postoperatifyatış süresine sahiptir. Laparaskopik adrenalektomilerde deneyim artıkça daha uzun olan ameliyat süresi kısalacaktır. Öğrenme eğrisi tamamlandığı zaman adrenal hastalıklarda laparaskopik adrenalektomi altın standart olarak tercih edilmelidir.

Anahtar Kelimeler: Adrenalektomi; Cerrahi ; Laparoskopi

$\begin{array}{ll}\text { Received } & : 23 \text { January } 2021 \\ \text { Accepted } & : 14 \text { April } 2021\end{array}$


A drenal masses are pathologies that are at high risk of malignancy and can be presented with very different clinical, laboratory and radiological features. Today, there has been a significant increase in the introduction of high-tech radiological diagnostic methods and the development of diagnostic tests and the detection of adrenal gland masses (1).

Adrenal masses show a fairly deep and well-restricted settlement in the abdominal area. These masses can be benign or malignant, and hormone active or non-active. The separation of benign and malignant adrenocortical masses can be difficult (2). During radiological examinations for various reasons not related to adrenal glands, or during the laparotomies coincidentally found; in anamnesis, physical examination, asymptomatic adrenal masses that do not show adrenal mass or adrenal dysfunction are called incidentalome. Most of these masses, which are detected by chance, are benign lesions (cysts, adenomas) and are usually cortical adenomas that are not of disruptive properties and are randomly detected as a result of radiological examinations. Incidence ranges from $1.4 \%$ to $8.7 \%(4.5 \%)$.

The masses of the adrenal gland are classified as histopathological adenoma, adrenal gland cancer, pheochromocytoma, myelolipoma, ganglioneuroma, oncocytoma, adrenal gland cyst, hemangioma, metastases of the adrenal gland and other pathologies (3). In these masses, surgical treatment is applied to lesions, which are thought to be hyper secretive or malignant. Today, adrenalectomy is recommended on lesions of $5 \mathrm{~cm}$ or above, which are detected by abdominal tomography or magnetic resonance imaging techniques (4). Laparascopic and robotic surgery has been preferred in adrenal gland diseases in the last 30 years with an increasing rate (5). In this study, the diagnostic methods and surgical treatments of 106 patients who had adrenal mass were detected in the General Surgery Clinic and underwent adrenalectomies analyzed.

\section{Material \& Methods}

In our study, 106 patients who were operated due to adrenal mass in our hospital general surgery clinic retrospectively examined by obtaining approval from the ethics committee of our hospital. (11.11.2013/208) Demographic information of all patients (age, gender, tumor size, tumor weight, localization, adrenal disease) were investigated from file records. Also, routine blood and urine hormone examinations were recorded and included in the study to determine whether the masses were functional for patients who were found to have adrenal mass with radiological examinations. Laboratory examinations of blood cortisol and aldosterone values were measured. Cortisol levels, valine mandelic acid (VMA), metanephrine and nonmetanephrine levels of urine samples of the patients were also assessed. All of the masses removed from the surgery were histopathologically examined.

The localization and size of the masses were determined using radiological examinations such as computed tomography (CT) and magnetic resonance imaging (MRI). Surgical intervention was performed on masses that were hormonally active, larger than $5 \mathrm{~cm}$ in diameter, suspected malignancy or symptomatic. Subcostal, paramedian or median incisions were prefered in open adrenalectomy. Laparoscopic interventions were performed with a transabdominal lateral approach. Morbidity, operative time and length of hospital stay of the patients underwent surgery were evaluated. Lapararoscopic and open surgery subgroups were compared in terms of postoperative early and late complications, mortality, and hospital stay time.

\section{Statistical Analyses}

The data were evaluated using a statistical package for the Social Sciences (SPSS) 25 for Windows (SPSS ${ }^{\circledR}$ Inc. Chicago, IL, USA program. Comparing categorical data between groups, Pearson Chi-Square, and Fisher's Exact test, comparing continuous data between two groups, Mann Whitney $\mathrm{U}$, Kruskal Wallis $\mathrm{H}$ (post hoc Bonferroni corrective Mann Whitney U) statistical analyses were considered statistically significant. $(p<0.005)$

\section{Results}

One hundred and six patients who had an adrenal mass and underwent adrenalectomy were retrospectively evaluated. The demographic characteristics, side and duration of the surgery, size and weight of the tumour, hospital stay time, number of early and late complications and preoperative functional status of the 106 patients are shown in Table 1.

When the indications of the patients were examined, 67 (63.2\%) were operated due to non-functional adrenal mass. In the functional patient group, 10 (9.4\%) patients were diagnosed with cushing syndrome and the other 29 (27.3\%) patients were operated due to symptoms of pheochromocytoma. One of the patients diagnosed with cushing syndrome was radiologically bilateral mass and the remaining nine patients were operated due to unilateral 
Table 1. Age, gender, side, size and weight of mass, operative time, length of hospital stay, imaging techniques, complications and preoperative functional status of patients

\begin{tabular}{|c|c|c|c|c|c|}
\hline & & \multicolumn{2}{|c|}{ Surgery Type } & \multirow{2}{*}{ Total } & \multirow{2}{*}{$\mathrm{p}$} \\
\hline & & Laparoscopic & Open & & \\
\hline \multirow[t]{2}{*}{ Gender } & Male $\mathrm{n}(\%)$ & $8(7.5 \%)$ & $34(32 \%)$ & $42(39.6 \%)$ & \multirow{2}{*}{0.288} \\
\hline & Female n(\%) & $18(16.9 \%)$ & $46(4.3 \%)$ & $64(60.4 \%)$ & \\
\hline \multicolumn{2}{|l|}{ Age (years) } & $47.2 \pm 12.55$ & $51.7 \pm 12.72$ & $50,61 \pm 12,77$ & 0.009 \\
\hline \multirow{3}{*}{ Side } & Left $n(\%)$ & $12(11.3 \%)$ & $26(24.5 \%)$ & $38(35.8 \%)$ & \multirow{3}{*}{0.047} \\
\hline & Right n(\%) & $11(10.3 \%)$ & $52(49 \%)$ & $63(59.4 \%)$ & \\
\hline & Bilateral n(\%) & $3(2.8 \%)$ & $2(1.8 \%)$ & $5(4.7 \%)$ & \\
\hline \multicolumn{2}{|l|}{ Size $(\mathrm{cm})$} & $4.67 \pm 1.72$ & $6.35 \pm 3.07$ & & 0.072 \\
\hline \multicolumn{2}{|l|}{ Weight (gr) } & $35.38 \pm 26.12$ & $96.67 \pm 120.16$ & & $0.001^{*}$ \\
\hline \multicolumn{2}{|l|}{ Operative time (min) } & $151.19 \pm 16.2$ & $133.55 \pm 12.2$ & & 0.219 \\
\hline \multicolumn{2}{|l|}{ Length of hospital stay (day) } & $4 \pm 1.54$ & $5.15 \pm 2.33$ & & 0.110 \\
\hline \multicolumn{2}{|l|}{ Early complication n(\%) } & 0 & $16(15 \%)$ & 16 & 0.013 \\
\hline \multicolumn{2}{|l|}{ Late complication n(\%) } & 0 & $9(8 \%)$ & 9 & 0.074 \\
\hline \multirow{3}{*}{ Preoperative functional status } & Pheochromocytoma (n) & $8(7.5 \%)$ & $21(19.8 \%)$ & $29(27.3 \%)$ & \multirow{3}{*}{0.789} \\
\hline & Cushing Syndrome (n) & $3(2.8 \%)$ & $7(6.6 \%)$ & $10(9.4 \%)$ & \\
\hline & Non-functional (n) & $15(14.1 \%)$ & $52(49 \%)$ & $67(63.2 \%)$ & \\
\hline \multirow{3}{*}{ Imaging technique } & CT & $5(4.7 \%)$ & $38(35.8 \%)$ & $43(40.5 \%)$ & \\
\hline & MRI & $21(19.8 \%)$ & $42(39.6 \%)$ & $63(59.4 \%)$ & \\
\hline & $\mathrm{CT}+\mathrm{MRI}$ & $9(8.4 \%)$ & $15(14.1 \%)$ & $26(24.5 \%)$ & \\
\hline
\end{tabular}

mass. The patient with a bilateral mass was also functional and unilateral subtotal adrenalectomy was performed. Five patients who were operated due to the clinic of pheochromocytoma underwent cortex preserving adrenalectomy. Sixtythree (59.4\%) of radiologically detected masses were on the right and thirtyeight (35.8\%) on the left as seen on Table 1. No statistically significant difference was found between the laparoscopic and open surgery groups in terms of demographic characteristics, except for the weight of the masses ( $p<0.005)$.

Radiological examination methods used for localization of masses are shown in Table 1. Histopathological examination of sixtyseven patients who were operated due to non-functional adenoma revealed that 37 (34.9\%) of these patients actually have adrenocortical adenoma. The pathology results of ten (9.4\%) patients who were operated due to clinical or subclinical Cushing syndrome was adenoma. Other pathological diagnoses (adrenocortica hyperplasia, malignant epithelial tumor metastasis, myelolipoma, schwannoma, cyst (haemorrhagic, adrenocortical, endothelial), ganglioneuroma) are shown in Table 2.
$80(75.4 \%)$ of the 106 patients detected were open adrenalectomy, and laparoscopic lateral transabdominal intervention was preferred for 26 (24.6\%). Fifteen (57\%) of patients started laparoscopically were suspended for various reasons such as bleeding, insufficent exposure, difficulty of manuplation and hemodynamic insatbility. These fifteen patients were included in open group for analyses. In $61(82.4 \%)$ of the 80 patients undergoing open adrenalectomy were subcostal incision, 17 (22.9\%) median incision, and paramedian incision was preferred in 2 (2.7\%).

The mean duration of laparoscopic adrenalectomy was $151.19 \pm 16.27$ minutes (min), while the mean time of the subcostal incision was $132.93 \pm 11.27 \mathrm{~min}$, while the mean time of the median incision was $136.12 \pm 16.02 \mathrm{~min}$. The mean operation time of the two patients who were operated by paramedian incision was $130.5 \pm 3.54$ min. A statistically significant difference between the operation times of cases according to incision selection $(p<0.05)$. Duration of surgery who were operated laparoscopically was statistically high in the duration of patients with median and subcostal incision ( $p=0.0083$ )(Table 3 ). The mean weight and size of the masses after histopathological examination were given in detail in Table 2. 


\begin{tabular}{|c|c|c|c|c|c|c|}
\hline & & \multicolumn{4}{|c|}{ Pathological Diagnose } & \multirow{2}{*}{ Total } \\
\hline & & Pheochromocytoma & Adrenocortical Adenoma & Adrenocortical Carcinoma & Other* & \\
\hline \multirow{2}{*}{$\begin{array}{l}\text { Hormone } \\
\text { Active }\end{array}$} & $\begin{array}{l}\text { Pheochromocytoma } \\
\mathrm{n}(\%)\end{array}$ & $29(27.3 \%)$ & & & & $29(27.3 \%)$ \\
\hline & $\begin{array}{l}\text { Cushing Syndrome } \\
\mathrm{n}(\%)\end{array}$ & & $10(9.4 \%)$ & & & $10(9.4 \%)$ \\
\hline $\begin{array}{l}\text { Nonhormone } \\
\text { active }\end{array}$ & Nonfunctional n(\%) & & $37(34.9 \%)$ & $5(4.7 \%)$ & $25(23.5 \%)$ & $67(63.2 \%)$ \\
\hline \multicolumn{2}{|l|}{ Weight (gr) } & $124,52 \pm 142,02$ & $44,22 \pm 43,72$ & $245 \pm 165,48$ & $59,1 \pm 73,5$ & \\
\hline \multicolumn{2}{|c|}{ Median(Min.-Max.) } & $65(23-691)$ & $25(8-220)$ & $190(75-450)$ & $40(5-310)$ & \\
\hline \multicolumn{2}{|l|}{ Size $(\mathrm{cm})$} & $6,9 \pm 2,54$ & $4,83 \pm 2,19$ & $9 \pm 2,55$ & $6,25 \pm 4,7$ & \\
\hline \multicolumn{2}{|c|}{ Median(Min.-Max.) } & $6,75(2-14)$ & $4,75(1,5-14)$ & $9(5-12)$ & $5,5(2,5-20)$ & \\
\hline
\end{tabular}

When file records are examined; in 16 patients (15\%) wound infections, evisseration and postoperative bowel obstruction developed within first thirty days which were evaluated as early complications. Eight patients (7.5\%) developed postoperative wound infection, while postoperative bowel obstruction was observed in three patients (2.8\%). One of these three patients also developed evisseration (0.9\%). Incisional hernias which developed in long-term from scars after discharge, were also evaluated as late complications. In 9 patients (8.4\%) incisional hernia was observed during postoperative period. All of the patients who developed incisional hernia were found to have been operated by median incision. Postoperative complications in early and late periods were observed in surgeries that were performed with a preference of median and subcostal incision. Statistically significant difference between groups was found in terms of postoperative complication rates according to incision type $(p=0.001)$ (Table 4). As a result of the operations, no patients had mortality.

\begin{tabular}{|l|c|c|c|c|}
\hline Table 3. Type of incision subgroup and operative time \\
\hline & \multicolumn{5}{|c|}{ Operative time (min) } \\
\hline Incision type & Time & Median & Min. & Max. \\
\hline Laparoscopic $(\mathrm{n}=26)$ & 151,19 & 148,5 & 130 & 195 \\
\hline Median incision $(\mathrm{n}=17)$ & 136,12 & 133,0 & 115 & 170 \\
\hline Paramedian incision $(\mathrm{n}=2)$ & 130,5 & 130,5 & 128 & 133 \\
\hline Subcostal incision $(\mathrm{n}=61)$ & 132,93 & 132,0 & 112 & 160 \\
\hline
\end{tabular}

According to type of operation, a statistically significant difference between the length of hospital stay of the patients $(p<0.05)$. Open surgery group patients hospital stay times were found to be statistically significantly higher than laparoscopic patients staying in hospital $(p=0.012)$ (Table 1).

A statistically significant difference between the length of hospitalization of cases according to incision subgroup $(p<0.05)$. Duration of hospital stay for the patients operated by median incision was found to be longer than that of patients operated with laparoscopic adrenalectomy and subcostal incision( $p=0.001$ )(Table4).

\begin{tabular}{|c|c|c|c|c|c|c|c|}
\hline \multirow{2}{*}{ Incision type } & \multicolumn{4}{|c|}{ Stay Time (day) } & \multicolumn{2}{|c|}{$\begin{array}{l}\text { Postoperative } \\
\text { complications }\end{array}$} & \multirow{2}{*}{$\mathrm{P}$} \\
\hline & Mean & Median & Min. & Max. & $\begin{array}{l}\text { Early } \\
\mathrm{n}(\%)\end{array}$ & $\begin{array}{l}\text { Late } \\
\mathrm{n}(\%)\end{array}$ & \\
\hline Laparoscopic & 4 & 3,5 & 2 & 9 & - & - & \multirow{4}{*}{0,001} \\
\hline $\begin{array}{l}\text { Median } \\
\text { incision }\end{array}$ & 7,12 & 6,0 & 2 & 13 & $\begin{array}{c}8 \\
(7.5 \%)\end{array}$ & $\begin{array}{c}9 \\
(8.4 \%)\end{array}$ & \\
\hline $\begin{array}{l}\text { Paramedian } \\
\text { incision }\end{array}$ & 3 & 3,0 & 2 & 4 & - & - & \\
\hline $\begin{array}{l}\text { Subcostal } \\
\text { incision }\end{array}$ & 4,67 & 5,0 & 2 & 11 & $\begin{array}{c}8 \\
(7.5 \%)\end{array}$ & - & \\
\hline
\end{tabular}




\section{Discussion}

Adrenal masses can be presented with very different clinical, laboratory and radiological data. Furthermore, adrenal masses are lesions that carry an approxiamtely 4-12\% risk of malignancy (6). In many publications, it is observed that patients are in the 6 th decade $(3,7)$.

The incidence of incidental masses found in children is more likely to be malignant. It is also known that the risk of cancer increases as the size of the mass increases.

$4 \mathrm{~cm}$ and greater adenomas in the 12,000 autopsy series 4 $\mathrm{cm}$ and greater adenomas $4 ; 6 \mathrm{~cm}$ and greater adenomas were rarely reported (8). In our series, the mean size of the masses detected in pheochromocytoma is $6.9 \pm 2.54 \mathrm{~cm}$ $(2-14 \mathrm{~cm})$, the mean size of the masses detected in adenomas is $4.83 \pm 2.19 \mathrm{~cm}(1,5-14 \mathrm{~cm})$, the mean size of the masses detected in adrenal cortical carcinoma $9 \pm 2.55 \mathrm{~cm}(5-$ $12 \mathrm{~cm}$ ), benign reported (Myelolipoma, ganglioneuroma, adrenal cyst, schwannoma) was found to have an mean size of $6.25 \pm 4.07 \mathrm{~cm}(2.5-20 \mathrm{~cm})$. In our series, 46 patients had a mass of more than $6 \mathrm{~cm}$, and adrenocortical carcinoma was detected in $4(8.6 \%)$ of these cysts.

Adrenal malignancies are generally large and very few are small. Some pathologists also report that size is the most important criterion for the differential diagnosis of benign or malignant adrenal masses (9). Based on these results and the lack of biochemical and imaging methods to make benign/malignant separation definitively in adrenal tumor, they recommend surgical excision in all nonfunctioning adrenal incidentalomas, taking into account that they encounter a high level of malignity (10). In our series, adrenocortical carcinoma was found in 5 patients (4.7\%) and the mean size of these masses was found $9 \pm 2.55 \mathrm{~cm}$ (5-12cm).

Among the exact diagnostic criteria are those who think that using the dimension can cause serious misconceptions. Waiting for a small audience to increase in size may mean giving time to turn into carcinoma and invasive. And once the disease progresses, it will be easier to diagnose malignancy. This will not allow early diagnosis and radical surgical intervention. Treatment of nonfunctional adrenal masses with diameters between 3 and $6 \mathrm{~cm}$ is controversial. Many surgeons are concerned about the follow-up of these masses and recommend surgery (11).

Adrenal malignancies may be cystic. Because some of the masses identified as adrenal cysts are pseudocysts caused by cystic degeneration in a pathological gland. Some recommend the exploration of all adrenal cysts to uncover an underlying malignancy (12). The adrenal cyst was detected in 5 patients in our series and no cancer was detected in the pathological examination of these cases.

Although adrenalectomy can be performed with classical open technique in very large tumors that show an invasive environmental tissue with no obvious boundaries, and give the image of heterogeneity, recent studies have shown the effectiveness of laparoscopic technique in adrenal tumors larger than $6 \mathrm{~cm}$ and no signs of malignancy.

Besides, laparoscopic surgery can now be performed with evolving techniques even in tumors with larger masses and surrounding tissue invasion (13). In our study, laparoscopic surgery was performed on unilateral and under $5 \mathrm{~cm}$ masses. However, as laparoscopic experience increases, it is also thought to be applied in larger tumors.

In the literature, the mean operation time in laparoscopic adrenalectomy performed with the transperitoneal approach was 80 to 360 minutes (14). In our series, the duration of operation of patients undergoing laparoscopic intervention was $151.19 \pm 16.27$ minutes. According to the open approach, this difference, which is statistically significantly more than that, is thought to depend on our laparoscopic learning curve.

In literature, the transition to open approach in laparoscopic adrenalectomy is approximately $2 \%(0-13 \%)(15)$. The most common causes of exposure are small venous bleeding. Also, inferior vein or renal vein injuries may be included in this group. Local or vascular invasion due to malignancy during laparoscopy is another problem of exposure. Other situations include abdominal adhesions, organ injuries, diaphragma injury, obesity, massive hepatomegaly and giant benign tumors (16). In our series, $15(36 \%)$ of the 41 patients we started laparoscopic were suspended and the majority of these cases were intended not to increase the complication rate due to lack of experience in laparoscopy.

The rate of operative complications is $5-10 \%$ in laparoscopic adrenalectomy performed in experienced centers, and this rate is often higher in open adrenalectomy (17). In our series, 21 patients (19.8\%) developed complications early and/or late. Statistically significant difference between groups was found in terms of postoperative complication rates according to incision type $(p=0.001)$. 
In European and American publications, the mean length of hospital stay in the laparoscopic method is 3 days, and the open method is 6.5 days on average.(18) In our series, patients who underwent open surgery and preferred subcostal incision have an mean hospital stay of $4.67 \pm 1.76$ days, median incision preferred patients $7.12 \pm 3.1$ days, paramedian incision preferred patients $3 \pm 1.41$ days, and laparoscopic surgery patients have an mean hospital stay period of $4 \pm 1.55$ days. As a result, it can be argued that complications can be prevented, and that minimally invasive surgery can achieve its goal in terms of its advantages $(19,20)$.

\section{Conclusion}

In selected patient groups, laparoscopic adrenalectomy causes shorter postoperative hospitalization time and less postoperative complications than open adrenalectomy. Therefore, laparoscopic adrenalectomy preferences are increasing day by day, and even in large tumors and surrounding tissue invasions, laparoscopy is the first preferred method.

\section{References}

1. Prager G, Heinz-Peer G, Passler C, et al. Surgical strategy in adrenal masses. Eur. J. Radiol. 2002;41:70-7. DOI:10.1016/ s0720-048x(01)00441-7

2. Amberson JB, Vaughan ED, Jr., Gray GF, et al. Flow cytometric analysis of nuclear DNA from adrenocortical neoplasms. A retrospective study using paraffin-embedded tissue. Cancer. 1987;59:20915. $\quad$ DOI:10.1002/1097-0142(19870615)59:12<2091::aidcncr2820591221>3.0.co;2-u

3. Mantero F, Terzolo M, Arnaldi G, et al. A survey on adrenal incidentaloma in Italy. Study Group on Adrenal Tumors of the Italian Society of Endocrinology. J. Clin. Endocrinol. Metab. 2000;85:63744. DOI:10.1210/jcem.85.2.6372

4. Di Buono G, Buscemi S, Lo Monte Al, et al. Laparoscopic adrenalectomy: preoperative data, surgical technique and clinical outcomes. BMC Surg. 2019;18:128. DOI:10.1186/s12893-018-0456-6

5. Fu B, Li H, Ma X, et al. Robotic Adrenalectomy. In: Zhang X, ed. Laparoscopic and Robotic Surgery in Urology: Springer; 2020. $p$. 25-33.

6. Dinnes J, Bancos I, Ferrante Di Ruffano L, et al. MANAGEMENT OF ENDOCRINE DISEASE: Imaging for the diagnosis of malignancy in incidentally discovered adrenal masses: a systematic review and meta-analysis. Eur. J. Endocrinol. 2016;175:R51-64. DOI:10.1530/ EJE-16-0461

7. Luton JP, Martinez M, Coste J, et al. Outcome in patients with adrenal incidentaloma selected for surgery: an analysis of 88 cases investigated in a single clinical center. Eur. J. Endocrinol. 2000;143:111-7. DOI:10.1530/eje.0.1430111

8. Copeland PM. The incidentally discovered adrenal mass. Ann. Surg. 1984;199:116-22. DOI:10.1097/00000658-198401000-00021

9. Lau SK and Weiss LM. The Weiss system for evaluating adrenocortical neoplasms: 25 years later. Hum. Pathol. 2009;40:75768. DOI:10.1016/j.humpath.2009.03.010
10. Fassnacht M, Arlt W, Bancos I, et al. Management of adrenal incidentalomas: European Society of Endocrinology Clinical Practice Guideline in collaboration with the European Network for the Study of Adrenal Tumors. Eur. J. Endocrinol. 2016;175:G1-G34. DOI:10.1530/EJE-16-0467

11. Gaujoux S, Mihai R, Joint Working Group Of E, et al. European Society of Endocrine Surgeons (ESES) and European Network for the Study of Adrenal Tumours (ENSAT) recommendations for the surgical management of adrenocortical carcinoma. Br. J. Surg. 2017;104:358-76. DOI:10.1002/bjs.10414

12. Fassnacht $M$, Dekkers $O M$, Else $T$, et al. European Society of Endocrinology Clinical Practice Guidelines on the management of adrenocortical carcinoma in adults, in collaboration with the European Network for the Study of Adrenal Tumors. Eur. J. Endocrinol. 2018;179:G1-G46. DOI:10.1530/EJE-18-0608

13. Fiori $C$, Checcucci $E$, Amparore $D$, et al. Adrenal tumours: open surgery versus minimally invasive surgery. Curr. Opin. Oncol. 2020;32:27-34. DOI:10.1097/CCO.0000000000000594

14. Chalkoo M, Awan N, Makhdoomi H, et al. Laparoscopic Adrenalectomy; A Short Summary with Review of Literature. 2017.

15. RaffaelliM, DeCreaC and BellantoneR.Laparoscopicadrenalectomy. Gland Surg. 2019;8:S41-S52. DOI:10.21037/gs.2019.06.07

16. Koçak $S$ and Özbaş S. Endoskopik Adrenalektomi. Turkiye Klinikleri Journal of Surgical Medical Sciences. 2007;3:29-36.

17. Aporowicz $M$, Domosławski $P, C z o p n i k ~ P$, et al. Perioperative complications of adrenalectomy-12 years of experience from a single center/teaching hospital and literature review. Archives of medical science: AMS. 2018;14:1010.

18. Lodin M, Privitera A and Giannone G. Laparoscopic adrenalectomy (LA): keys to success: correct surgical indications, adequate preoperative preparation, surgical team experience. Surg. Laparosc. Endosc. Percutan. Tech. 2007;17:392-5. DOI:10.1097/ SLE.0b013e3180f6174b

19. Chan JE, Meneghetti AT, Meloche RM, et al. Prospective comparison of early and late experience with laparoscopic adrenalectomy. Am. J. Surg. 2006;191:682-6. DOI:10.1016/j.amjsurg.2006.01.042

20. Haveran LA, Novitsky YW, Czerniach DR, et al. Benefits of laparoscopic adrenalectomy: a 10-year single institution experience. Surg. Laparosc. Endosc. Percutan. Tech. 2006;16:21721. DOI:10.1097/00129689-200608000-00004 